\title{
Long-term follow-up after transplantation of insulin-producing pancreatic islets into patients with Type 1 (insulin-dependent) diabetes mellitus
}

\author{
G. L. Warnock ${ }^{1,3}$, N.M.Kneteman ${ }^{1,3}$, E.A. Ryan ${ }^{2}$, A. Rabinovitch ${ }^{3}$ and R.V. Rajotte ${ }^{1,2,3}$ \\ Departments of ${ }^{1}$ Surgery, ${ }^{2}$ Medicine and ${ }^{3}$ Surgical Medical Research Institute, University of Alberta, Edmonton, Canada
}

\begin{abstract}
Summary. Purified human islets and a kidney from the same donor were transplanted into four patients with Type 1 (insulin-dependent) diabetes mellitus. Two of the patients received additional islets that were isolated from multiple donors, cryopreserved, and stored in a tissue bank. The islets were embolized into the liver via the portal vein. Immunosuppression was induced with antilymphocyte globulin and maintained with azathioprine, prednisone and cyclosporine. In the first two patients, fasting serum C-peptide rose to levels of $0.5-2.0 \mathrm{ng} / \mathrm{ml}$ during the first 4-8 weeks and mixed meal feeding elicited increases to $2-3 \mathrm{ng} / \mathrm{ml}$. C-peptide secretion persisted for 8 months, but at progressively lower levels and insulin therapy could not be withdrawn. In the next two patients who received cryopreserved islets in addition to fresh islets, serum C-peptide levels (fasting/post-meal) rose to $4-7 \mathrm{ng} / \mathrm{ml}$ and serum glucose was more stable, allowing withdrawal of insulin therapy after 69 days in one patient,
\end{abstract}

and reduced insulin doses in the other. The insulin-independent patient has maintained normal fasting glucose, glycosylated haemoglobin, and oral glucose tolerance at 1 year following cessation of daily insulin therapy. Episodes of renal graft rejection occurred in three patients, including the insulin-independent patient. High-dose steroid therapy reversed the rejection in all instances, with apparent preservation of C-peptide secretion. These data show that transplantation of purified freshly-prepared and cryopreserved islets into Type 1 diabetic patients results in prolonged insulin secretion, and that sufficient function could be provided in one patient to sustain euglycaemia in the absence of insulin therapy at 1 year of follow-up.

Key words: Pancreatic islet transplantation, Type 1 (insulindependent) diabetes mellitus, cryopreservation.
Studies of islet transplantation began in 1972, when procedures to isolate and transplant purified islets were reported in laboratory rodents [1]. Unfortunately, islet isolation techniques led to prohibitively low yields from the compact, fibrous human pancreas, resulting in failure of clinical islet transplantation. An alternative approach was to eliminate purification steps that resulted in large losses of islets, however, this did not solve the problems [2]. Insufficient islet tissue implanted, inadequate immunosuppression (resulting in rejection), and complications of portal hypertension and sepsis remained as obstacles to successful clinical islet transplantation. Recently, advances have been made in isolation of purified islets [3-5], definition of the critical islet mass to be transplanted [6], effective tissue banking by cryopreservation [7], and improved immunosuppression. In earlier brief communications, we reported our initial application of these advances to the treatment of patients who suffered from Type 1 (insulin-dependent) diabetes mellitus with end-stage diabetic nephropathy $[8,9]$. In the present report, we de- tail the long-term follow-up studies of graft function in our first four patients.

\section{Subjects, materials and methods}

\section{Pancreas procurement}

Pancreas was obtained from adult human cadaver organ donors at the University of Alberta and its teaching hospitals in Edmonton. The pancreas was removed immediately after laparotomy by dividing the gastrocolic omentum and splenic ligaments, then the tail of the gland was mobilized en bloc with the spleen and its vessels. The origin of the splenic artery and the junction of the splenic and portal veins were identified. The neck of the pancreas was freed from the portal vein and the remainder of the gland was detached from the retroperitoneum, care being taken to preserve the splenic vessels and their blood perfusion until just before excision. The gland was transected at the neck, leaving a portion of the uncinate process and head in situ, then excised. The pancreas was weighed and immersed into $4^{\circ} \mathrm{CHanks}$ ' balanced salt solution (HBSS). The pancreatic duct at the head was cannulated with a 16 gauge cannula and then HBSS- 
Table 1. Characteristics of patients with Type 1 (insulin-dependent) diabetes mellitus (recipients) and islets transplanted

\begin{tabular}{|c|c|c|c|c|c|c|c|c|}
\hline \multicolumn{4}{|c|}{ Islet recipients } & \multicolumn{5}{|c|}{ Islet donation } \\
\hline Patient & $\begin{array}{l}\text { Age } \\
\text { (years) }\end{array}$ & Sex & $\begin{array}{l}\text { Type } 1 \\
\text { diabetes } \\
\text { (years) }\end{array}$ & $\begin{array}{l}\text { Islet type } \\
\text { (No. of } \\
\text { donors) }\end{array}$ & $\begin{array}{l}\text { Islet } \\
\text { total } \\
\left(\mathrm{x} 10^{3}\right)\end{array}$ & $\begin{array}{l}\text { Islet } \\
\text { No./kg }\end{array}$ & $\begin{array}{l}\text { Islet } \\
\text { volume } \\
\mu \mathrm{l} / \mathrm{kg}\end{array}$ & $\begin{array}{l}\text { HLA } \\
\text { Match }\end{array}$ \\
\hline 1 & 35 & $\mathrm{M}$ & 17 & fresh $(1)$ & 261 & 4000 & 7 & $1 \mathrm{~A}, 1 \mathrm{DR}$ \\
\hline 2 & 26 & M & 20 & fresh (1) & 261 & 4000 & 7 & Nil \\
\hline 3 & 35 & $\mathbf{F}$ & 25 & $\begin{array}{l}\text { fresh (1) } \\
\text { cryo (4) }\end{array}$ & $\begin{array}{l}243 \\
368\end{array}$ & $\begin{array}{l}4000 \\
6100\end{array}$ & $\begin{array}{r}7 \\
11\end{array}$ & $\begin{array}{l}4 \mathrm{AB}, 0 \mathrm{DR} \\
4 \mathrm{AB}, 0 \mathrm{DR}\end{array}$ \\
\hline & & & & TOTAL & $\overline{611}$ & $\overline{10100}$ & 18 & \\
\hline 4 & 41 & $\mathrm{M}$ & 18 & $\begin{array}{l}\text { fresh (1) } \\
\text { cryo (10) }\end{array}$ & $\begin{array}{l}117 \\
779\end{array}$ & $\begin{array}{r}1600 \\
10800\end{array}$ & $\begin{array}{r}3 \\
19\end{array}$ & $\begin{array}{l}1 \mathrm{AB}, 0 \mathrm{DR} \\
9 \mathrm{AB}, 5 \mathrm{DR}\end{array}$ \\
\hline & & & & TOTAL & $\overline{896}$ & $\overline{12400}$ & 22 & \\
\hline
\end{tabular}

M, male; F, female.

${ }^{a}$ C-peptide $<0.1 \mathrm{ng} / \mathrm{ml}$ fasting and after challenge with a mixed meal (Sustacal) and with glucagon. ${ }^{\mathrm{b}}$ Islets were isolated from the number of human organ donors indicated, and implanted in the recipient with Type 1 diabetes, within $24 \mathrm{~h}$ of renal transplantation

containing collagenase (Sigma, St. Louis, Mo., USA type XI, $2772 \mathrm{U} / \mathrm{ml}, 100-150 \mathrm{ml}$ at $4^{\circ} \mathrm{C}$ ) was injected. The pancreas was transported immediately to the islet isolation laboratory, where it was transferred to a cooling tray. The pancreatic duct was exposed at the middle of the gland, and two additional 16 gauge cannulas were inserted into this portion of the duct, one directed proximally and the other distally. The duration of hypothermic storage was less than $1.5 \mathrm{~h}$.

\section{Islet isolation}

Procedures have been detailed previously [4]. Each pancreatic duct cannula was connected to a custom-designed stainless steel perfusion device and a solution containing collagenase was perfused through the cannula, initially at $4^{\circ} \mathrm{C}$, then gradually warmed to $38^{\circ} \mathrm{C}$. Tissue biopsies were removed, dissociated, and examined by microscopy. Digestion of the pancreas was judged complete when the islets dissociated freely from the exocrine tissue. The digested tissue was transferred to HBSS containing $2 \%$ (volume/volume) newborn calf serum (Gibco, Burlington, Ontario, Canada) at $4^{\circ} \mathrm{C}$ and gently teased apart. The tissue was washed, triturated through needles of progressively smaller sizes $(14,16$ gauge), and suspended in tissue culture medium 199 (TCM 199, Gibco) at $4^{\circ} \mathrm{C}$ using $0.6 \mathrm{~g}$ of tissue per $3.4 \mathrm{ml}$ of medium. Aliquots of $4.0 \mathrm{ml}$ of tissue suspensions were mixed with $4.3 \mathrm{ml}$ of $5 \times$ TCM 199 and $16.7 \mathrm{ml}$ of Ficoll (Sigma, density 1.125 ) in disposable $50 \mathrm{ml}$ conical tubes and overlaid with successive $5 \mathrm{ml}$ aliquots of Ficoll with densities of 1.085, 1.075, 1.045 . The tubes were centrifuged at $550 \times \mathrm{g}$ for $25 \mathrm{~min}$ at $22^{\circ} \mathrm{C}$. Tissue that layered at the 1.045/1.075 and 1.075/1.085 interfaces was collected, washed, and resuspended in a known volume of culture medium.

\section{Cryopreservation}

Aliquots of 10,000 islets were transferred to Kimax tubes in $0.5 \mathrm{ml}$ of TCM 199 with $25 \mathrm{mmol} / \mathrm{l}$ HEPES and supplemented with $10 \%$ fetal calf serum and penicillin/streptomycin. The cryoprotectant dimethyl sulphoxide (DMSO) was added stepwise to a final concentration of $2 \mathrm{~mol} / \mathrm{l}$. Following a nucleation step, the tubes were slowly cooled at $0.25^{\circ} \mathrm{C} / \mathrm{min}$ to $-40^{\circ} \mathrm{C}$, and plunged to $-196^{\circ} \mathrm{C}$ for storage for periods of 3 months to 2 years before they were thawed [7]. A rapid thawing rate of $150^{\circ} \mathrm{C} / \mathrm{min}$ was used to $0^{\circ} \mathrm{C}$, and the DMSO removed using a sucrose dilution followed by a serial dilution using TCM 199 containing $10 \%$ human serum at $37^{\circ} \mathrm{C}$.

\section{Islet assessment}

Aliquots of freshly-isolated or cryopreserved islets were incubated with dithizone, a compound which stains islet endocrine cells red [9]. Dithizone-positive islets larger than $50 \mu \mathrm{m}$ were counted and sized immediately before transplantation using a microscope fitted with an optical graticule. The number of islets of various diameter sizes was converted to a number of islets with an average diameter of $150 \mu \mathrm{m}[10]$ and their volume in microlitres was calculated with the assumption that each was a sphere. Purity was assessed by comparing the relative proportions of dithizone-positive and unstained tissue. Islet viability for each set of donor islets was individually assessed in vitro by measuring insulin secretory response during perifusion with glucose [12]. Insulin was measured by double antibody RIA [13] using human insulin standards and kits (Pharmacia Diagnostics, Uppsala, Sweden).

\section{Patients and transplantation procedures}

Details of the clinical transplantation data are presented in Table 1. All patients had Type 1 diabetes, confirmed by serum C-peptide less than $0.1 \mathrm{ng} / \mathrm{ml}$ after a 12 - $\mathrm{h}$ fast and 90 min after oral ingestion of $360 \mathrm{ml}$ of Sustacal (Mead Johnson, Belleville, Ontario, Canada), a liquid mixed meal containing $50 \mathrm{~g}$ of carbohydrate, $22 \mathrm{~g}$ of protein, and $9 \mathrm{~g}$ of fat. The patients suffered from a $17-25$ year history of Type 1 diabetes that resulted in neuropathy, retinopathy, and endstage diabetic nephropathy. All patients received a cadaver renal allograft as well as islets isolated from the pancreas of the kidney donor. For islet implantation, a midline laparotomy was performed. In the first two patients, the middle colic vein was cannulated, thereby gaining access to the portal vein. In the second two patients, patency of the median umbilical vein was established and a catheter was advanced to the left portal vein. The islets were injected into the portal vein via these catheters within $24 \mathrm{~h}$ of islet isolation. This provided a total of 261,000 (patients 1 and 2), 243,000 (patient 3), and 117,000 (patient 4 ) freshly-isolated islets. In patient 3 , an additional 368,000 cryopreserved islets pooled from four donors were injected. In patient 4 , an additional 780,000 cryopreserved islets pooled from ten donors were injected on two separate occasions - at the time of injecting the freshly-isolated islets and again 1 week later. The dose of islets syngeneic with the donor kidney was 4000 islets $/ \mathrm{kg}$ body weight $(7 \mu \mathrm{l} / \mathrm{kg})$ in the first three patients and 1600 islets $/ \mathrm{kg}(3 \mu \mathrm{l} / \mathrm{kg})$ in patient 4 . The cryopreserved islet dose in patient 3 was 6100 islets $(11 \mu \mathrm{l}) / \mathrm{kg}$ and in patient 4 this was $10,800(19 \mu \mathrm{l}) / \mathrm{kg}$. All islets were matched for blood type, but serum cytotoxicity assays were not performed. Antigen matching for the kidney and islet transplants from 

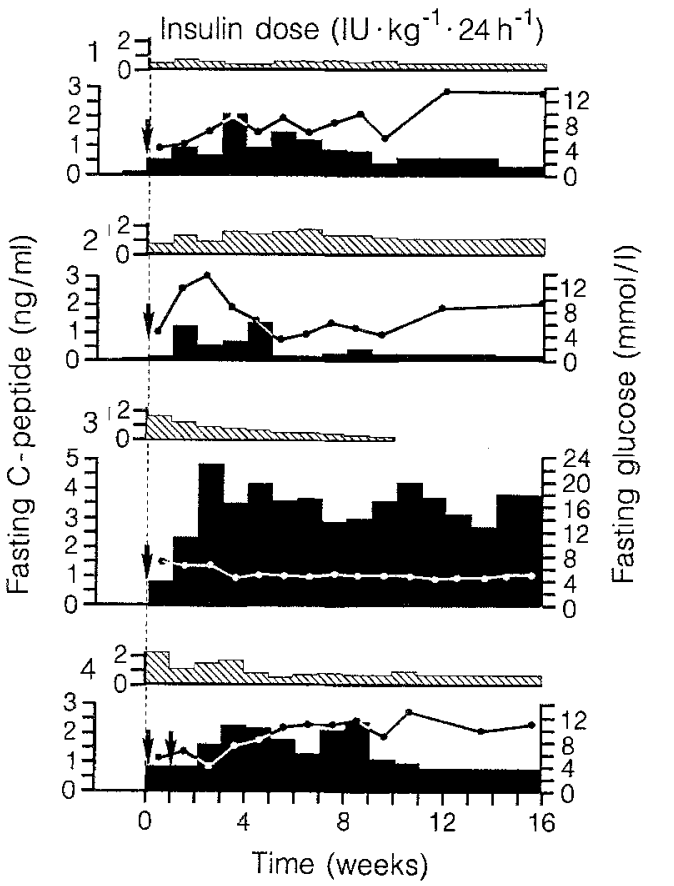

Fig. 1. Comparison of islet function (insulin requirements, fasting serum C-peptide and simultaneous glucose levels) during the first 16-weeks follow-up after islet implantation $(\downarrow)$ in four patients $(1-4)$

the same donor showed that one DR antigen was matched in the first recipient, but no DR antigens were matched in the other three recipients. For the cryopreserved islets infused from multiple donors, a total of four $\mathrm{AB}$ antigens (patient 3 ) and nine $\mathrm{AB}$ antigens (patient 4) were matched, while no DR antigens were matched in patient 3 and five were matched in patient 4 .

Immunosuppression was induced with a 10-day course of Minnesota antilymphoblast globulin (MALG), and maintained with azathioprine, prednisone, and cyclosporine A (CsA). CsA was in troduced at day 8 after transplantation (dose adjusted according to whole blood levels by monoclonal RIA) and azathioprine and prednisone were continued in tapering dosages. During the first 10 14 days, insulin was infused intravenously to maintain capillary blood glucose between 4 and $7 \mathrm{mmol} / \mathrm{l}$. During subsequent weeks, subcutaneous insulin was administered to maintain similar glycaemic levels. Fasting serum glucose and C-peptide levels were measured on venepuncture samples daily for 14 days, twice weekly for 10 weeks, then twice monthly. At weekly intervals, insulin therapy was withheld after 18.00 hours and serum C-peptide was measured after a 10 -h fast and $90 \mathrm{~min}$ after oral ingestion of $360 \mathrm{ml}$ of Sustacal by RIA [13] using kits (Incstar, Stillwater, Minn., USA).

\section{Results}

\section{Islet grafts}

The final packed cell volume of each injection of freshlyprepared and/or cryopreserved graft was from 1.0 to $2.5 \mathrm{ml}$. Morphologic examination immediately before transplantation showed that $80 \%$ of the endocrine volume was provided by islets that had diameters greater than $150 \mu \mathrm{m}$ and islets in the $200-249 \mu \mathrm{m}$ size range contributed the largest amount to the graft volume. Endocrine cell purity was approximately $75 \%$, as determined by dithizone staining of aliquots. Some of the islets had rims of exocrine tissue attached, but the majority were completely free. Before implantation, a biphasic insulin secretory response was observed during perifusion of both freshly-isolated and cryopreserved islets. Basal insulin release was $0.05-0.2 \mu \mathrm{U} \cdot$ islet $^{-1} \cdot \mathrm{min}^{-1}$ rising during glucose stimulation to $0.3-2.0 \mu \mathrm{U} \cdot$ islet $^{-1} \cdot \mathrm{min}^{-1}$ during the first phase and $0.25-1.0$ during the second phase.

\section{Patients}

All the patients survived the combined kidney and islet transplant procedures without morbidity attributable to the laparotomy incisions or islet catheters. The islet infusion procedure caused a transient epigastric pressure sensation in patient 3 , and was generally well-tolerated over all. Portal venous pressure remained normal in all patients. A transient rise in serum aspartate aminotransferase was detectable in three of the patients during the first $48 \mathrm{~h}$. Follow-up has been maintained for greater than 1 year in the first three patients, and 6 months in patient 4 . During this time, retinopathy has remained stable in patients 1,3 and 4 . In patient 2 , retinopathy progressed, but was stabilized by laser photocoagulation. Episodes of rejection of the transplanted kidney were observed in patients 2,3 and 4, but these were reversed successfully and subsequent function has remained stable for the duration of follow-up.

\section{Long-term islet graft function}

Figure 1 compares weekly fasting serum C-peptide levels, insulin requirements and simultaneous glucose levels in all four patients during the first 16 weeks after transplantation. Postoperatively, C-peptide secretion was detected immediately in all the patients. In the first two patients, Cpeptide rose to levels of $1.0-2.0 \mathrm{ng} / \mathrm{ml}$, at 5 weeks. Simultaneous fasting glucose levels ranged from $4-14 \mathrm{mmol} / \mathrm{l}$. Cytomegalovirus (CMV) infection, characterized by malaise, fever, and confirmed by positive blood cultures and serology developed at 4 weeks in patients 1 and 2 . Severe leucopoenia which accompanied the CMV infection necessitated cessation (patient 1) or reduction (patient 2) of azathioprine treatment beginning at 5 weeks. Following these episodes, C-peptide levels declined progressively and these declines were accompanied by elevation of fasting glucose levels. Although serum C-peptide continued to be detectable until 8 months, exogenous insulin supplements continued to be required in these first two patients. In patients 3 and 4 (both of whom received a combination of freshly-isolated and cryopreserved islets), higher levels of serum C-peptide were observed. In patient 3, C-peptide levels remained persistently elevated at $2.5-5.0 \mathrm{ng} / \mathrm{ml}$ and fasting glucose was maintained at 4-7 mmol/l, allowing withdrawal of daily exogenous insulin therapy at 9 weeks. Thereafter, C-peptide secretion and euglycaemia was maintained for a year (Fig. 2). In patient 4 , fasting C-peptide rose to levels of $0.8-2.4 \mathrm{ng} / \mathrm{ml}$ and serum glucose was 4-11 mmol/l. During prolonged 


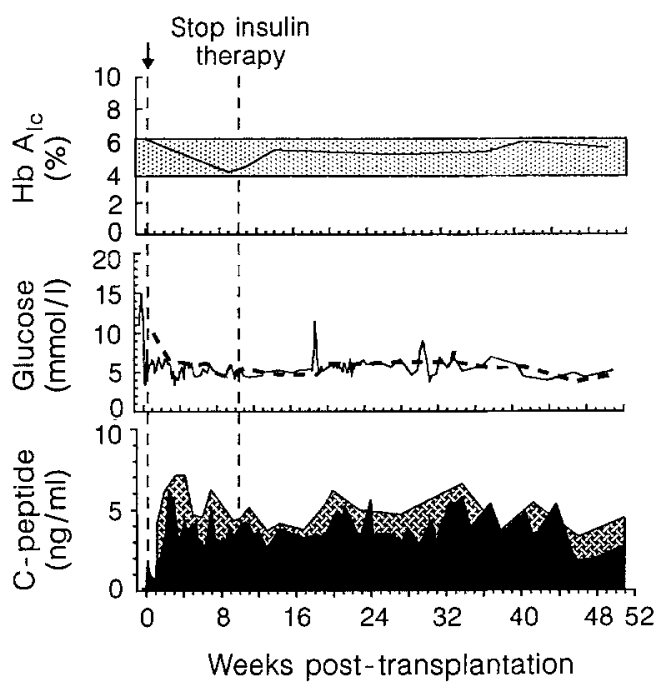

Fig. 2. Islet function during 1-year follow-up in patient 3 transplanted $(\downarrow)$ with approximately 600,000 islets (fresh plus cryopreserved). Insulin-independence was achieved by 9 weeks, $\mathrm{Hb}_{1 c}$ levels remained in the normal (1) range. Serum glucose levels remained normal during fasting (-) and after Sustacal therapy (-----), except during high-dose intravenous steroid therapy for renal rejection episodes at 18,24 , and 30 weeks. Serum C-peptide levels remained elevated from $2.5-5 \mathrm{ng} / \mathrm{ml}$ during fasting ( $\square$ ) and rose further after Sustacal meal challenge (路).

follow-up, C-peptide levels remained at $1-2 \mathrm{ng} / \mathrm{ml}$. Although exogenous insulin therapy could not be withdrawn, the requirements for insulin were reduced from $40 \mathrm{IU}$ to $25 \mathrm{IU}$ daily, fasting glucose was $4-11 \mathrm{mmol} / \mathrm{l}$, body weight has remained constant and glycated haemoglobin has remained in the high normal range.

\section{Metabolic studies}

Weekly oral ingestion of $360 \mathrm{ml}$ of Sustacal elicited a further rise in serum C-peptide levels to $1.5-3.0 \mathrm{ng} / \mathrm{ml}$ in patients 1 and 2 (up to 5 weeks after islet implantation) and in patient 4 up to 24 weeks at present. For patient 3 , the results of a 1-year follow-up of glycaemic control and weekly serum C-peptide responses to Sustacal meal challenge are shown in Figure 2. Serum $\mathrm{HbA}_{1 \mathrm{c}}$ remained within a range of $4.0-5.9 \%$ (normal $4.0-6.3 \%$ ). Fasting glucose remained less than $6.5 \mathrm{mmol} / \mathrm{l}$, except for 3 days during treatment of renal rejection with high-dose steroid therapy at 18,24 , and 30 weeks post-transplant. The serum glucose at $90 \mathrm{~min}$ after Sustacal ranged from $5.5-6.5 \mathrm{mmol} / 1$. C-peptide levels were $2.5-5.0 \mathrm{ng} / \mathrm{ml}$ before Sustacal and rose to $4-7 \mathrm{ng} / \mathrm{ml}$ at $90 \mathrm{~min}$ after Sustacal. After 44 weeks, the basal and incremental C-peptide levels were lower, which corresponded to a reduction of daily oral prednisone dosages from $10 \mathrm{mg}$ to $5.0 \mathrm{ng}$.

Figure 3 shows mean ( \pm SEM) serum glucose and corresponding $\mathrm{C}$-peptide and insulin profiles following oral mixed meal (Sustacal) feeding on eight occasions at $1-2$ monthly intervals in patient 3 during the year. The results are compared with ten normal age-matched nondiabetic control subjects. In patient 3 , glycaemic levels were slightly higher than in the control subject, but levels rose little or not at all during the 4-h period following the meal and normoglycaemia was maintained. Serum Cpeptide levels rose with the maximal response observed at $1 \mathrm{~h}$ in the patient and at $0.5 \mathrm{~h}$ for control subjects. Except for the $0.5 \mathrm{~h}$ occasion, C-peptide levels were higher in the transplant recipient. No deterioration of this $\mathrm{C}$ peptide response occurred during serial testing over the course of the year. Insulin levels at 1-year follow-up were higher than those observed in normal control subjects, except at $0.5 \mathrm{~h}$ post-Sustacal. The maximal insulin levels peaked at $0.5 \mathrm{~h}$ in normal control subjects and at $1 \mathrm{~h}$ in patient 3. During the Sustacal studies, the serum creatinine was consistently stable within a range of 95-110 $\mu \mathrm{mol} / 1$.

Response to oral injection of $75 \mathrm{~g}$ of dextrose in patient 3 at 1-year follow-up is shown in Figure 4. Serum glucose ranged from 5.3 to 10.2 and maximal levels were observed at $1 \mathrm{~h}$ after glucose ingestion. The values during the study are within the normal reference range.

\section{Islet graft function during renal graft rejection}

Clinical evidence for renal allograft rejection, characterized by an abnormal renal perfusion scan and progressive rise in serum creatinine was observed at 23 weeks in patients 2 and 4 , and three episodes occurred at 18,24 and 30 weeks in patient 3 . In each instance, highdose steroid therapy was administered (intravenous injections of methylprednisolone $250-500 \mathrm{mg}$ daily for three consecutive days). C-peptide levels continued to be de-
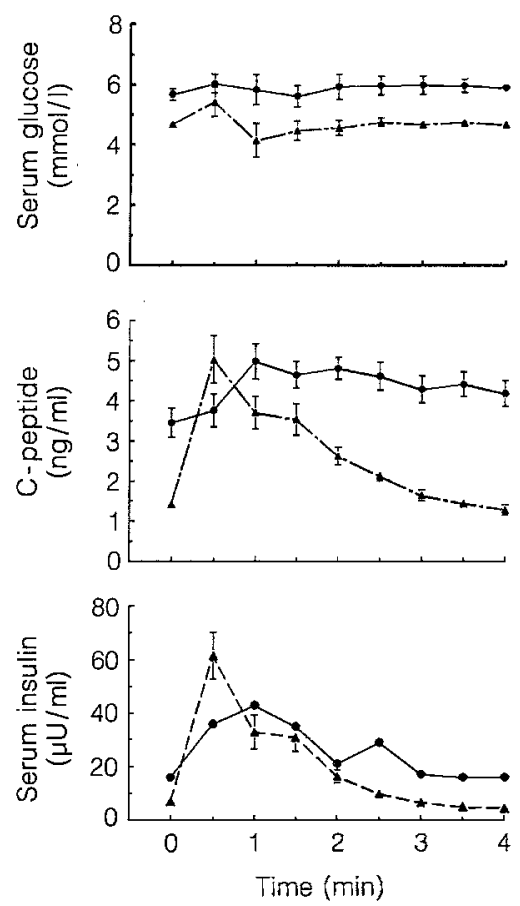

Fig. 3. Serum glucose and corresponding C-peptide levels at 12 month intervals $(-\bullet-n=8)$ in patient 3 during a 4 -h period following oral mixed meal challenge with Sustacal and serum insulin profiles at 1-year follow-up. For comparison, results of Sustacal challenge for ten normal age-matched control subjects are shown $(-\boldsymbol{A}-)$ 


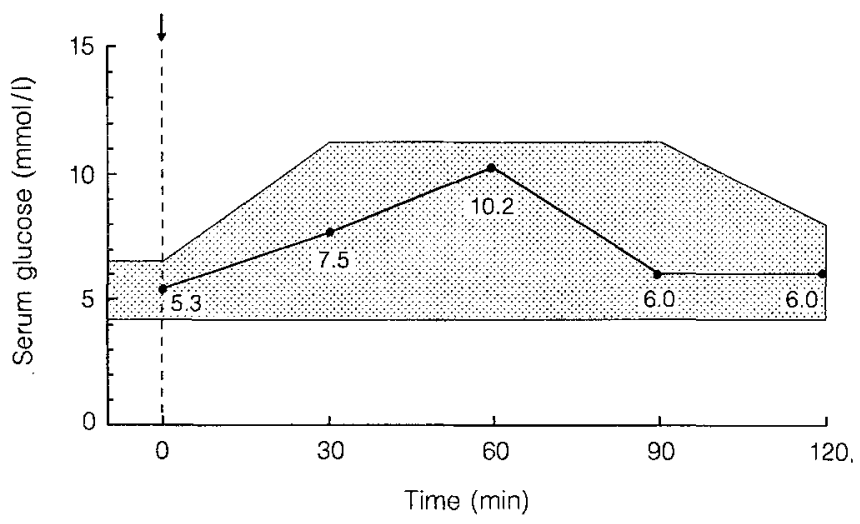

Fig.4. Glucose levels following oral glucose tolerance testing with $75 \mathrm{~g}$ of dextrose $(\measuredangle)$ in patient $3(--)$ at 1 year after islet transplantation, compared with normal reference range (ㄱ)

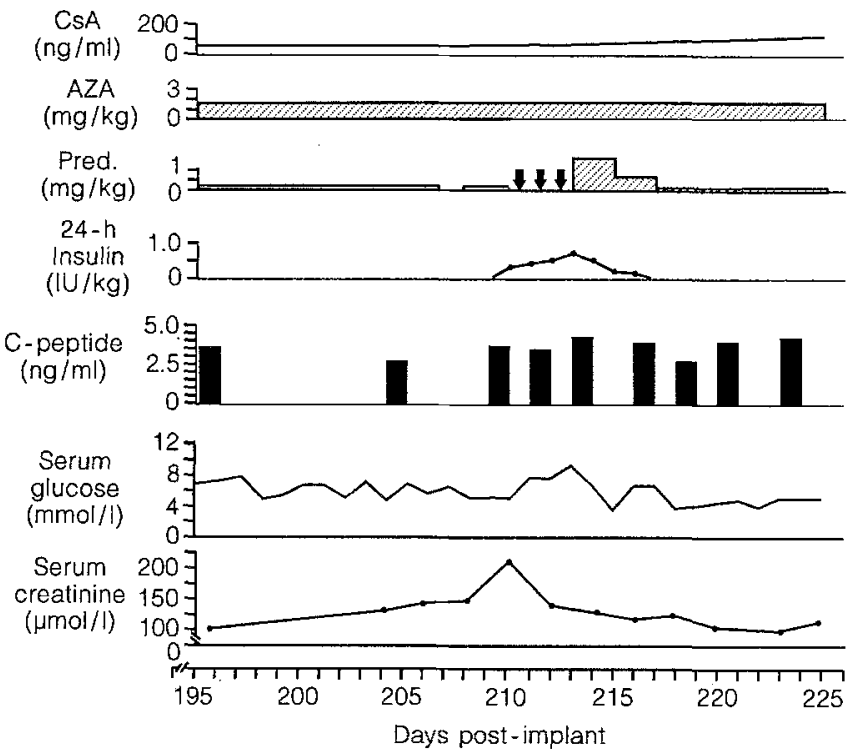

Fig.5. Profiles of immunosuppressive therapy with cyclosporine (CsA), azathioprine (AZA), and prednisone (Pred); insulin requirements; and serum C-peptide, glucose, and creatinine levels during the course of renal allograft rejection in patient 3 at 30 weeks postimplant. During the rise of serum creatinine, no significant change was observed in glucose levels or serum C-peptide. Insulin therapy was administered to sustain euglycaemia during treatment with $250 \mathrm{mg}$ of Solumedrol $(\downarrow)$ administered daily. When steroid therapy was stopped, insulin therapy was discontinued and C-peptide production and euglycaemia were maintained

tectable after these episodes in all patients. An example of one of the episodes of renal rejection at 30 weeks in the third patient is shown in Figure 5. The serum creatinine rose from 103 to $207 \mu \mathrm{mol} / \mathrm{l}$ from day 195 to day 210 . During this time, the fasting serum glucose levels remained normal. High-dose steroid therapy was instituted, then glucose levels rose to $8-9 \mathrm{mmol} / \mathrm{l}$ and insulin supplements were administered to sustain euglycaemia. Serum creatinine levels declined returned to normal in response to the high-dose steroid therapy. When high-dose steroid therapy was stopped, euglycaemia was maintained in the absence of insulin therapy. Fasting serum C-peptide levels remained constant before and after treatment for renal graft rejection, and even increased to higher levels when the dose of steroids was increased.

\section{Discussion}

Transplantation of insulin-secreting tissue offers a physiologic approach to restoration of precise glycaemic control and inhibition of the progressive neurovascular complications of Type 1 diabetes [15]. Pancreas transplantation has become popular since 1966, and results of over 2000 grafts have been reported to the International Pancreas Transplant Registry as of 1991 [16]. Analysis of recent reports of transplanting this organ reveals that the insulin-requiring state is reversed in $60 \%$ of recipients at 1 -year follow-up, $\mathrm{HbA}_{1 \mathrm{c}}$ is normalised and nephropathy can be prevented in kidneys that are transplanted simultaneously [17]. Despite these achievements in clinical pancreatic transplantation, transplantation of islets of Langerhans might be a more attractive approach because of low morbidity and the opportunity to manipulate the islets in attempts to reduce the amount of chronic immunosuppression the recipients require.

Recent clinical studies have held promise for transplantation of isolated islets into patients with diabetes. A major advance has been an increase in the quantity of islets implanted. Several approaches have made this possible. First, improvements in islet isolation techniques have yielded greater quantities of islets while preserving islet viability. Although the first two patients received an islet mass that we found predictive of a non-insulin requiring state in dogs, function was clearly insufficient to reverse long-term insulin dependence. Indeed, the serum C-peptide levels obtained (basal 1-2 ng/ml, and Sustacalstimulated $1.5-3.0 \mathrm{ng} / \mathrm{ml}$ ) were about half those reported in non-insulin requiring diabetic recipients of vascularized pancreas grafts [18], suggesting that a larger islet mass was required, or that the extent of islet engraftment needed to be improved.

A second approach which has provided increased quantities of islets for individual recipients has been to inject islets from multiple donors. This has enabled improved islet function in a Type 1 diabetic patient [19]. Using this approach, Scharp et al. reversed insulin-dependence for 12 days in a Type 1 diabetic patient [20]. These studies contrast with the findings of Tzakis et al., who found that the best results for glycaemic control were provided by islets from a single donor for some patients who had pancreatectomy-induced diabetes after abdominal exenteration [21].

A third approach is to isolate islets, then cryopreserve and store them in a tissue bank until sufficient tissue is collected for implantation. In our study, the improved function of the islet graft in patients 3 and 4 is likely to be attributable to the supplemental mass of cryopreserved islets, since these patients had higher C-peptide levels while the dose of freshly isolated islets was constant or lower than in the first two recipients. This approach also has been reported recently by Scharp et al. [22]. In one of the patients who received additional cryopreserved islets in our study, 
islet function fell short (C-peptide levels) of that achieved in patient 3 (associated with insulin independence), despite apparent adequacy of islet mass and viability. The reason for this in patient 4 is not clear, but may have been due to early rejection of some of the cryopreserved islets, or increased susceptibility of frozen-thawed islet grafts to toxicity of immunosuppressive drugs, as we have observed in dogs (unpublished observations).

The mass of islet tissue which reversed insulin-dependence in one of the present patients was 10,000 islets $(18 \mu \mathrm{l}) / \mathrm{kg}$ of recipient body weight. Although dose-response studies would be needed in more cases to establish the islet mass needed to achieve insulin independence, this quantity of islets agrees with the islet mass needed to reverse insulin therapy in another patient [22]. This mass of islet tissue is considerably higher than the quantity (approximately 5000 islets $/ \mathrm{kg}$ ) found predictive for reversal of diabetes in acutely pancreatectomized dogs [23]. This discrepancy may be attributable to insulin resistance from the chronic Type 1 diabetic state and steroid immunosuppression [24, 25]. These factors may also account for the finding that fewer islets were needed by Tzakis et al., who achieved partial or complete glycaemic control in five of nine pancreatectomized patients who received FK 506 immunosuppression [20].

Examination of the long-term course of C-peptide secretion in this study yields several observations. In the first two patients, a delayed decline in C-peptide release was observed over a period of 1-3 months. In our two patients, this began after onset of $\mathrm{CMV}$ infection. This suggests that primary CMV infection may be deleterious to islet function, and is reminiscent of a similar observation by Sutherland et al. [2], however, other factors may have been operative. In our cases, the accompanying leucopoenia necessitated a reduction in azathioprine therapy, and this may have resulted in islet rejection, or onset of a recapitulated Beta-cell specific autoimmune destruction of islets. A final explanation may have been degranulation and exhaustion of an initially marginal mass of intraportal islets, as has been observed in animal studies [23, 26, 27]. In contrast to the findings of delayed decline of islet function in the two recipients of a smaller islet mass, the islet function was sustained in one of the two patients who received larger islet dosages.

The patient who achieved insulin-independence and euglycaemia is the first unequivocal example of successful islet cell transplantation for a 1-year duration in a Type 1 diabetic patient. Metabolic studies in this patient show that euglycaemia is sustained during mixed meal feeding, and that the islet Beta-cell function did not deteriorate during 1 year of follow-up. Despite this finding, the kinetics of C-peptide and insulin release were not normal. The peak early C-peptide response was delayed, which is consistent with earlier observations in dogs [23], and may be attributable to reduced islet mass or islet denervation. Also, high levels of serum C-peptide were observed in this euglycaemic patient, which is consistent with a need for elevated insulin secretion in the face of insulin resistance, a common observation in pancreas [18] and renal [25] transplant patients. In this patient, the levels of higher Cpeptide secretion were closely related to treatment with high-dose steroid therapy rather than to impaired renal function.

Renal allograft rejection episodes were detectable on five occasions in three patients in the present study. At these times, serum C-peptide levels were reduced or unchanged, and following treatment in all cases, the C-peptide levels improved. These data suggest that islet failure or damage is not the obligatory outcome of rejection of a simultaneously implanted kidney. Despite these encouraging findings in this group of patients, rejection remains the main problem that limits clinical application of islet transplantation in Type 1 diabetes. Experimental studies suggest that a vascularized organ allograft from the same donor might reduce the immune barrier to islet acceptance [28] although this explanation might not apply to the cryopreserved islets.

The present studies show that islet transplantation is feasible for inducing sustained ( 1 year) euglycaemia and insulin-independence in a Type 1 diabetic patient. Success is enhanced by increasing the islet mass transplanted by adding cryopreserved islets that are collected from other human donors and stored in a tissue bank. This represents an essential preliminary step toward evaluating islet transplantation as a therapy to prevent the serious late complications of diabetes mellitus.

Acknowledgements. This study was supported by grants from the Alberta Heritage Foundation for Medical Research, the Medical Research Council of Canada, the Edmonton Civic Employees'Charitable Assistance Fund, the Muttart Diabetes Research and Training Centre, the Juvenile Diabetes Foundation International, the General Hospital (Grey Nuns) of Edmonton, the Alberta Foundation for Diabetes Research, and the University of Alberta Hospitals. The authors thank Ms. D. Untch, Ms. H. Powers, and Mr. D. Bracewell for technical help and are grateful to Ms. C. Gardner for invaluable secretarial assistance.

\section{References}

1. Ballinger WF, Lacy PE (1972) Transplantation of intact pancreatic islets in rats. Surgery 72: 175-186

2. Sutherland DER, Matas AJ, Goetz FC, Najarian JS (1980) Transplantation of dispersed pancreatic islet tissue in humans: autografts and allografts. Diabetes $29: 31-44$

3. Gray DWR, McShane P, Grant A, Morris PJ (1984) A method for isolation of islets of Langerhans from the human pancreas. Diabetes 33: 1055-1061

4. Warnock GL, Ellis D, Rajotte RV, Dawidson I, Baekkeskov S, Egebjerg J (1988) Studies of the isolation and viability of human islets of Langerhans. Transplantation 45: 957-963

5. Ricordi C, Lacy PE, Finke EH, Olack BJ, Scharp DW (1988) Automated method for isolation of human pancreatic islets. Diabetes 37: 413-420

6. Warnock GL, Rajotte RV (1988) Critical mass of purified islets that induce normoglycemia after implantation into dogs. Diabetes 37: 467-470

7. Rajotte RV, Warnock GL, Coulombe MG (1988) Islet cryopreservation: methods and experimental results in rodents, large mammals and humans. In: van Schilfgaarde R, Hardy MA (eds) Transplantation of the endocrine pancreas in diabetes mellitus. Elsevier, Amsterdam, pp 125-135

8. Warnock GL, Kneteman NM, Ryan EA et al. (1989) Continued function of pancreatic islets after transplantation in type I diabetes. Lancet II: $570-572$ 
9. Warnock GL, Kneteman NM, Ryan E, Seelis REA, Rabinovitch A, Rajotte RV (1991) Normoglycaemia after transplantation of freshly-isolated and cryopreserved pancreatic islets in Type 1 (insulin-dependent) diabetes mellitus. Diabetologia 34: 55-58

10. Bonnevie-Nielsen V, Skovgaard LT, Lernmark Å (1983) B-cell function relative to islet volume and hormone content in the isolated perfused mouse pancreas. Endocrinology 112: 1049-1056

11. Ricordi C, Gray DWR, Hering BJ et al. (1990) Islet isolation assessment in man and large animals. Acta Diabetol Lat 27: 185-195

12. Lacy PE, Walker MN, Finke GJ (1972) Perifusion of isolated rat islets: in vitro participation of the microtubular system in the biphasic release of insulin. Diabetes 21:987

13. Morgan CR, Lazarow A (1963) Immunoassay of insulin: two antibody system. Diabetes $12: 1.15$

14. Krause V, Von Erdmann B, Atzpodien W, Beyer J (1981) C-peptide measurement: a simple method for the improvement of specificity. J Immunoassay 2: 33

15. Mauer SM, Steffes MW, Sutherland DER, Najarian JS, Michael AF, Brown DM (1975) Studies of the rate of regression of the glomerular lesion in diabetic rats treated with pancreatic islet transplantation. Diabetes 24: 280-285

16. Sutherland DER, Gillingham K, Moudry-Munns KC (1991) Registry report on clinical pancreas transplantation. Transplant Proc 23: 55-57

17. Bohman SO, Tyden G, Wilczek H et al. (1985) Prevention of kidney graft diabetic nephropathy by pancreas transplantation in man. Diabetes 34: 306-308

18. Smith JL, Hunsicker LG, Yuh WTC, Wright FH Jr, Van Voorhis L, Corry RJ (1989) Appearance of type II diabetes mellitus in type I diabetic recipients of pancreas allografts. Transplantation 47:304-311

19. Mintz DH, Alejandro R, Miller J (1988) Human islet transplantation: the University of Miami experience. In: van Schilfgaarde R, Hardy M (eds) Transplantation of the endocrine pancreas in diabetes mellitus. Elsevier, Amsterdam, pp 234-239
20. Scharp DW, Lacy PE, Santiago IV et al. (1990) Insulin independence after islet transplantation into type I diabetic patient. Diabetes 39: 515-518

21. Tzakis AG, Ricordi C, Alejandro R et al. (1990) Pancreatic islet transplantation after upper abdominal exenteration and liver replacement. Lancet 336: 402-405

22. Scharp DW, Lacy PE, Santiago JV (1991) Results of our first nine intraportal islet allografts in type 1 , insulin-dependent diabetic patients. Transplantation 51: 76-85

23. Warnock GL, Cattral MS, Rajotte RV (1988) Normoglycemia after implantation of purified islet cells in dogs. Can J Surg 31: 421-426

24. Yki-Järvinen H, Koivisto VA (1986) Natural course of insulin resistance in type I diabetes. New Engl J Med 315:224-230

25. Ekstrand A, Ahonen J, Gronhagen-Riska C, Groop L (1989) Mechanisms of insulin resistance after kidney transplantation. Transplantation 48:563-568

26. Alejandro R, Latif Z, Noel J et al. (1986) Natural history of intrahepatic canine islet cell autografts. J Clin Invest 78: 1339-1348

27. Sutton R, Gray DWR, McShane P, Peters M, Morris PJ (1987) The metabolic efficiency and long-term fate of intraportal islet grafts in the cynomolgus monkey. Transplant Proc 19:3575-3576

28. Morris PJ (1983) Combined liver and pancreatic islet transplantation in the rat. Transplantation 36: 230-231

Received: 1. August 1991

and in revised form: 23 September 1991

Dr. G. L. Warnock

University of Alberta

Surgical-Medical Research Institute

1074 Dentistry/Pharmacy Building

Edmonton, Alberta T6G 2N8

Canada

\section{Announcements}

\section{XXXIIIes Journees de Diabetologie de L'Hotel-Dieu}

This congress will take place from 18-20 June 1992 at the Palais des Congres de Paris, Paris, France. For further information please contact: Ms. Annick Forge, Secrétaire, Journées de Diabétologie, HotelDieu, 1, place du Parvis Notre-Dame, F-75181 Paris Cedex 04, France. Tel: (1) 42348388, Fax: (1) 43541564

\section{Diabetic renal disease in NIDDM patients: a major universal health problem}

One day symposium to be held on Monday, 7 September 1992 , before the 28th Annual Meeting of the EASD, in Prague, Czechoslovakia. For further information please contact: Prof. C. E. Mogensen, Second University Clinic of Internal Medicine, Aarhus Kommunehospitalet, DK-8000 Aarhus C, Denmark. 